\section{Influence of Seed Vigor and Preplant Herbicides on Emergence, Growth, and Yield of Tomato}

\author{
Cosme A. Argerich ${ }^{1}$, Kent J. Bradford, and Floyd M. Ashton ${ }^{3}$ \\ University of California, Davis, CA 95616
}

Additional index words. Lycopersicon esculentum, seed priming, seed aging, germination rate, napropamide, metribuzin

\begin{abstract}
The interactions of seed vigor with herbicides were studied with respect to seedling emergence, growth, and fruit yield of processing tomatoes (Lycopersicon esculentum Mill. cv. UC204C). Seed vigor (speed of germination) was enhanced by priming in an aerated solution of $0.12 \mathrm{M} \mathrm{K}_{2} \mathrm{HPO}_{4}$ plus $0.15 \mathrm{M} \mathrm{KNO}_{3}$ at $20 \mathrm{C}$ for 5 days followed by drying in forced air at 30C. The vigor of a second subsample of the same seed lot was reduced by controlled deterioration at $13 \%$ water content (dry-weight basis) for 6 days at 50C (aged seeds). Primed, aged, and untreated seeds were tested for their sensitivity to napropamide and metribuzin herbicides in greenhouse and field studies. A seed vigor $\times$ herbicide interaction was detected only under greenhouse conditions, where aged seeds were more sensitive than primed or untreated seeds to metribuzin. In April and May field plantings, seed vigor influenced the rate and percentage of final emergence and the earliness of fruit maturity, but had no effect on relative growth rate or total vegetative or reproductive yield. Napropamide at 4.5 and $9 \mathrm{~kg} \cdot \mathrm{ha}^{-1}$ and metribuzin at 0.4 and $0.8 \mathrm{~kg} \cdot \mathrm{ha}^{-1}$ had no effect on the rate or percentage of seedling emergence, relative growth rate, or total fruit yield. Metribuzin increased the mortality of seedlings at either application rate, and at $0.8 \mathrm{~kg} \cdot \mathrm{ha}^{-1}$ delayed early growth and fruit maturity in the April planting. Napropamide treatments did not differ from the water control for all characteristics and environments studied. Chemical names used: 4-amino-6-tert-butyl-3(methylthio)-1,2,4-triazin-5(4H)-one (metribuzin); 2-( $\alpha$-napthoxy)-N,N-diethyl propionamide (napropamide).
\end{abstract}

Stand establishment is a critical stage in the production of direct-seeded processing tomatoes, particularly in early plantings in cool soils. Both the final emergence percentage and the uniformity of seedling emergence influence the management and potential economic yield of the crop. Increasing use of expensive hybrid seed makes the success of crop establishment even more critical. Vigorous seeds are able to produce moreuniform seedlings that efficiently synthesize new materials and rapidly transfer them to the growing embryonic axis, resulting in increased seedling size and dry weight accumulation (McDonald, 1980).

Few studies have focused on the influence of seed vigor on seedling tolerance of pre-

Received for publication 27 Feb. 1989. Supported in part by a fellowship from the Instituto Nacioná de Tecnologia Agropecuaria, Argentina, to C.A.A., by a grant from Campbell's Seeds. Davis. Calif., and by Regional Research Project w-168. The cost of publishing this paper was defrayed in part by the payment of page charges. Under postal regulations, this paper therefore must be hereby marked advertisement solely to indicate this fact.

'Former graduate student, Dept. of Vegetable Crops. Current address: EEA INTA La Consulta, C.C. 8,5567 La Consulta, Mendoza, Argentina. ${ }^{2}$ Associate Professor, Dept. of Vegetable-Crops. To whom correspondence should be addressed. ${ }^{3}$ Professor Emeritus, Dept. of Botany. plant herbicides. In general, stand establishment was poorer in adverse seedbeds when seed of lower vigor was used, but herbicide injury was not significantly greater with lowvigor than with high-vigor seed of Glycine max L. (Johnson and Wax, 1979), Zea mays L. (Johnson and Wax, 1981), and Phaseolus vulgaris L. (Wyse et al., 1976). If variable seed vigor influences seedling metabolic and

Table 1. Effect of seed vigor and herbicides on the mean time to emergence (MTE) and the dry weight of tomato seedlings 15 days after MTE in a greenhouse trial. ${ }^{2}$

\begin{tabular}{lccc}
\hline \hline $\begin{array}{l}\text { Seed type or } \\
\text { herbicide used }\end{array}$ & $\begin{array}{c}\text { Application rate } \\
\left(\mathrm{kg} \cdot \mathrm{ha}^{-1}\right)\end{array}$ & $\begin{array}{c}\text { MTE } \\
(\text { degree-days })^{y}\end{array}$ & $\begin{array}{c}\text { Dry wt } \\
\text { (mg/plant) }\end{array}$ \\
\hline Seed type & & & \\
$\quad$ Untreated & & $53.7 \mathrm{~b}$ & $11.7 \mathrm{a}$ \\
Primed & $43.6 \mathrm{a}$ & $11.5 \mathrm{a}$ \\
Aged & & $79.2 \mathrm{c}$ & $8.1 \mathrm{~b}$ \\
Herbicide & 0 & 45.8 & 11.5 \\
None & 0.6 & 46.2 & 7.8 \\
Metribuzin & 1.1 & 45.6 & 5.2 \\
& 2.2 & 44.2 & 2.1 \\
Napropamide & 2.2 & 46.7 & 11.5 \\
& 4.5 & 46.3 & 8.7 \\
\hline
\end{tabular}

${ }^{\mathrm{T}}$ Mean separation in columns among seed vigor levels by LSD, 5\% level. MTE was not significantly influenced by herbicides. Dry weight was reduced linearly with increasing metribuzin concentrations $(P<0.05)$, but was unaffected by napropamide. The interaction of seed vigor $\times$ herbicides was nonsignificant.

'Degree-days calculated using a base temperature of 10C and averaged over diurnal temperatures as described in Baskerville and Emin (1969). growth rates, the ability to tolerate selective herbicides might also be affected. The purpose of this study was to investigate the establishment, growth, and yield of tomato trom seeds of different vigor levels plant herbicides.

Seeds of 'UC204C' tomato (Campbell's Seeds, Davis, Calif.) were treated by priming or controlled deterioration to either increase or decrease the germination rate, a sensitive indicator of vigor (Association of Official Seed Analysts, 1983). The priming treatment was 5 days in an aerated solution of $0.12 \mathrm{M} \mathrm{K}_{2} \mathrm{HPO}_{4}$ plus $0.15 \mathrm{M} \mathrm{KNO}_{3}(-1.25$ $\mathrm{MPa}$ osmotic potential) at $20 \mathrm{C}$ under flutight, followed by drying in forced basis). Another subsample of the same seed lot was aged at $13 \%$ water content (dry-weight basis) for 6 days at 50C and redried to the original water content $(6 \%)$. These priming and aging treatments were selected to increase and decrease, respectively, the rate of germination by $\approx 40 \%$ (Argerich and Bradford, 1989). Total germination was $>98 \%$ for control and primed seeds, and was reduced to $85 \%$ for the aged seeds (Argerich nd Bradford, 1989).

For greenhouse trials, primed, control ede pots of sandy-loam soil (1\% organic matter) mixed with $2.2,4.5$, or $9.0 \mathrm{~kg}$ (a.i.) of nametribuzin/ha. The temperature was maintained at 25/20C (day/night). The mean time to emergence (MTE) was calculated from the equation MTE $=\Sigma \mathrm{tn}_{1} / \Sigma \mathrm{n}_{\mathrm{i}}$, where $\mathrm{n}_{\mathrm{i}}$ is the number of newly emerged seedlings (cotyledon leaves unfolded) at time t. The time parameter was converted to a degree-days basis using a minimum temperature threshold of 10C, which was not affected by seed treatment (Argerich and Bradford, 1989), and 
Table 2. Effect of seed vigor and metribuzin on mean time to emergence (MTE) and tomato fruit yield and maturity in April and May field trials. ${ }^{2}$

\begin{tabular}{|c|c|c|c|c|c|c|c|}
\hline \multirow[b]{2}{*}{$\begin{array}{l}\text { Seed type } \\
\text { or herbicide } \\
\text { used }\end{array}$} & \multirow[b]{2}{*}{$\begin{array}{c}\text { Application } \\
\text { rate } \\
\left(\mathrm{kg} \cdot \mathrm{ha}^{-1}\right) \\
\end{array}$} & \multicolumn{3}{|c|}{ April planting } & \multicolumn{3}{|c|}{ May planting } \\
\hline & & $\begin{array}{c}\text { MTE } \\
\text { (degree-days) }^{y}\end{array}$ & $\begin{array}{c}\text { Total } \\
\text { fruit } \\
\text { fresh wt } \\
\left(\mathrm{t} \cdot \mathrm{ha}^{-1}\right)\end{array}$ & $\begin{array}{l}\text { Green } \\
\text { fruit } \\
(\%)\end{array}$ & $\begin{array}{c}\text { MTE } \\
\text { (degree-days) }{ }^{y}\end{array}$ & $\begin{array}{l}\text { Total } \\
\text { fruit } \\
\text { fresh wt } \\
\left(\mathrm{t} \cdot \mathrm{ha}^{-1}\right)\end{array}$ & $\begin{array}{l}\text { Green } \\
\text { fruit } \\
(\%)\end{array}$ \\
\hline \multicolumn{8}{|l|}{ Seed type } \\
\hline Untreated & & $57 \mathrm{a}$ & $118 \mathrm{a}$ & $14 \mathrm{a}$ & 109 a & $98 \mathrm{a}$ & $7.5 \mathrm{a}$ \\
\hline Primed & & $52 \mathrm{~b}$ & $117 \mathrm{a}$ & $15 \mathrm{a}$ & $103 \mathrm{~b}$ & $98 \mathrm{a}$ & $7.7 \mathrm{a}$ \\
\hline Aged & & $84 \mathrm{c}$ & $116 \mathrm{a}$ & $18 \mathrm{~b}$ & $161 \mathrm{c}$ & $94 \mathrm{a}$ & $9.7 \mathrm{~b}$ \\
\hline \multicolumn{8}{|l|}{ Herbicide } \\
\hline None (hand-weeded) & 0 & 65 & 114 & 13 & 124 & 99 & 8.1 \\
\hline Metribuzin & 0.4 & 64 & 121 & 17 & 123 & 98 & 10.9 \\
\hline & 0.8 & 64 & 108 & 21 & 122 & 92 & 9.7 \\
\hline
\end{tabular}

${ }^{2}$ Mean separation in columns among seed vigor levels by LSD, 5\% level. Metribuzin significantly affected only the percentage of green fruit in the April trial, where increasing concentrations of metribuzin linearly increased green fruit percentages $(P<0.05)$. Data for napropamide treatments are not shown as they did not differ significantly from the control. The interaction of seed vigor $x$ herbicides was nonsignificant.

'Degree-days calculated using a base temperature of 10C and averaged over diurnal temperatures as described in Baskerville and Emin (1969).

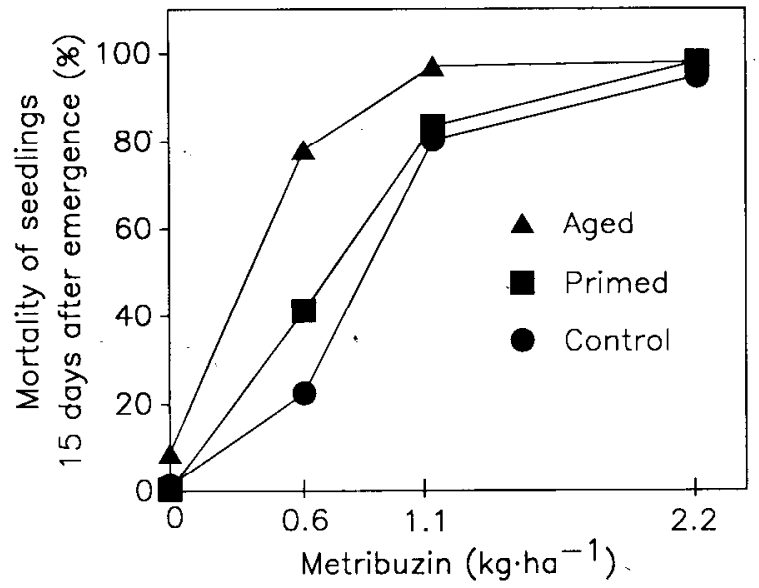

Fig. 1. Effect of metribuzin on the mortality of tomato plants 15 days after the mean emergence date for each seed treatment (primed, aged, or control $=$ untreated). The data represent the percentage of emerged seedlings that subsequently died. The experiment was conducted in pots in the greenhouse with metribuzin incorporated into the soil at the indicated rates. The herbicide rate $\mathrm{x}$ seed vigor interaction was highly significant $(P<0.01)$.

a maximum temperature threshold of $32 \mathrm{C}$ using a single sine formula (Baskerville and Emin, 1969). Fifteen days after the mean emergence date for each seed treatment, seedling mortality and shoot dry weights were determined.

Field trials were conducted on a Yolo loam soil (Typic Xerofluvents, 2\% organic matter) on two planting dates: 2 Apr. and 6 May 1987. Herbicide rates were 4.5 and $9.0 \mathrm{~kg}$ of napropamide/ha and 0.4 and $0.8 \mathrm{~kg}$ of metribuzin/ha. Herbicides were applied on the soil surface with a boom sprayer at 470 liters-ha-' and were incorporated $10 \mathrm{~cm}$ into the surface with a rototiller. Immediately thereafter, 200 live seeds (based on standard germination percentages) from each seed vigor level were planted $3 \mathrm{~cm}$ deep in single rows on 1.5-m-wide beds. A split-plot design was employed, with herbicide rates as the main plots, seed vigor levels as the subplots, and five replications. Plots were furrow-irrigated, and daily emergence counts were used to determine MTE based on degree-days calculated as above, using diurnal air temperature data recorded at a nearby weather station. Mortality of seedlings after emergence was evaluated at 15 days after the mean emergence date for each treatment. After thinning to single plants $20 \mathrm{~cm}$ apart, subsequent shoot growth was determined at 4or 5-day intervals by destructive harvest of $1-\mathrm{m}$ row sections. Shoots were dried to constant weight at $75 \mathrm{C}$ to determine dry weight. Destructive harvests of 3-m row sections of each plot were made at 124 and 118 days after planting for the April and May trials, respectively, and fruit maturity and yield and total shoot biomass were measured. The significance of mean differences was tested by analysis of variance with partitioning of the variances due to herbicide concentration into linear and residual components.

Herbicides did not affect seedling emergence in the greenhouse trial, regardless of seed vigor level. The aged seed lot had significantly $(P<0.05)$ fewer emerged plants $(70 \%)$ than the control $(98 \%)$ or primed $(99 \%)$ lots. Dry weights of seedlings 15 days after the mean emergence date were affected independently by herbicides and seed vigor, but no significant interaction was observed
(Table 1). At the lowest rate of metribuzin $\left(0.6 \mathrm{~kg} \cdot \mathrm{ha}^{-1}\right)$, the seedlings from aged seeds exhibited considerably greater mortality ( $\approx 80 \%)$ than did those from the control $(25 \%)$ or primed $(40 \%)$ seeds, resulting in a significant interaction between seed vigor and herbicide rate (Fig. 1). Napropamide had no effect on seedling mortality (data not shown) or dry weight (Table 1).

In field trials, seedling emergence percentages were reduced markedly by seed aging. In the April planting, emergence percentages were $80 \%, 85 \%$, and $30 \%$ for control, primed, and aged seeds, respectively, and the corresponding values for the May planting were $62 \%, 55 \%$, and $41 \%$. Mean times to emergence were also longer for aged seeds (Table 2). Herbicides had no effect on MTE (Table 2) or final seedling emergence percentage (data not shown). As in the greenhouse trial, metribuzin significantly increased seedling mortality after emergence for all seed lots (from 5\% for hand-weeded to $22 \%$ for the metribuzin treatments), but no significant interaction with seed vigor was detected. Seedling relative growth rates (slopes of ln dry weight vs. degree-days) were not affected by seed vigor or herbicides in either April or May trials, but the intercept of the $0.8-\mathrm{kg}$ metribuzin/ha treatment was significantly less than that of the control in the April trial (Fig. 2), indicating a detrimental effect of the herbicide on initial plant size. This inhibition of early growth resulted in delayed fruit maturity for the metribuzin treatments in the April trial (Table 2). Total fruit yield (Table 2) and shoot dry weight (not shown) were not significantly affected by seed vigor or herbicide treatments.

The absence of metribuzin effects on MTE or final emergence can be attributed to its mode of action as a photosynthetic inhibitor (Trebts and Wieroska, 1975). Once the seedlings became autotrophic, metribuzin markedly reduced dry weight gain and increased mortality in the greenhouse (Table 1; Fig. 1) and delayed initial plant growth in the April field trial (Fig. 2). Under conditions favorable to herbicide toxicity, as in the greenhouse $(50 \%$ less solar irradiation and less 


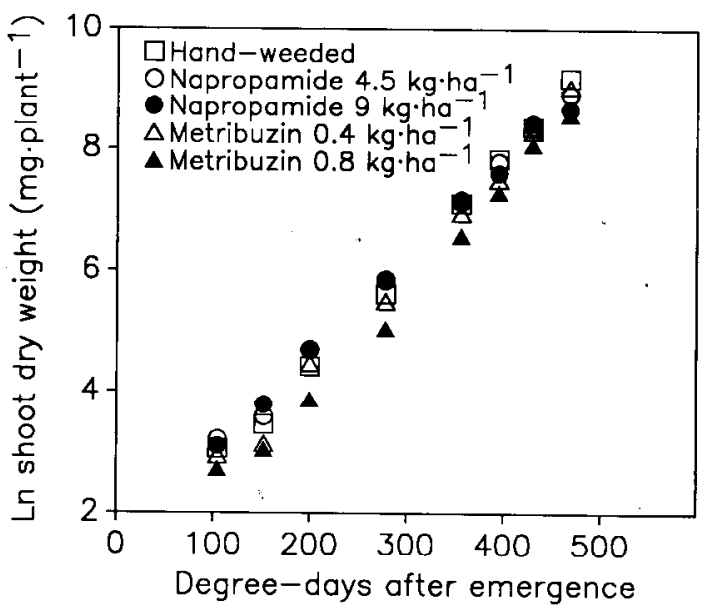

Fig. 2. Natural logarithms of tomato shoot dry weight accumulation for the herbicide treatments (pooled across seed vigor levels) as functions of degree-days after the mean emergence time in the April field trial. The slopes of the linear regressions of all treatments (i.e., the relative growth rates) were identical at 0.017 (ln $\mathrm{mg} / \mathrm{plant}$ per degree-day). The intercept for the $0.8 \mathrm{~kg} \cdot \mathrm{ha}^{-1}$ metribuzin treatment $(0.44 \mathrm{ln} \mathrm{mg/plant)}$ was significantly $(P<0.05)$ lower than that for the hand-weeded treatment $(0.94 \mathrm{ln} \mathrm{mg} /$ plant $)$, indicating a delay in initial plant growth in the presence of the herbicide.

soil volume than in the field), aged seeds suffered greater mortality from metribuzin than did control or primed seeds (Fig. 1). These results are in agreement with those of Johnson and Wax (1979) in soybeans, where S-propyl dipropylthiocarbamate (vernolate) was toxic only under greenhouse conditions. Similarly, an increase in phytotoxicity in cereals occurred in response to decreasing seed quality and increasing pesticide residues in soil pots under greenhouse conditions (Rajanna and de la Cruz, 1977). In the field, metribuzin reduced seedling dry weight and growth initially, but the plants subsequently recovered to the control growth rate (Fig. 2). The roots may eventually extend past the herbicide-treated zone, reducing uptake of the chemical. It is also possible that the use of glucose to detoxify the herbicide (Frear et al., 1983) could reduce the carbohydrate status of a small seedling but would be less significant for a larger plant with a greater assimilation rate.

The reduced early vegetative growth rate due to metribuzin was reflected in delayed fruit maturation without affecting total yield (Table 2). The reduced early growth was observed only in the April trial, in agreement with other reports that cold, wet, and cloudy conditions increase metribuzin phytotoxicity in tomatoes (Friensen and Hamill, 1978; Phatak and Stephenson, 1973). The accumulated degree-days and solar radiation during the emergence and early growth period were $8 \%$ and $10 \%$ greater, respectively, in May than in April (data not shown). The improved growth conditions in May apparently allowed the seedlings to grow more rapidly and escape the toxic effects of the herbicide.

No significant phytotoxicity symptoms were observed due to napropamide, even at the highest rate $\left(9 \mathrm{~kg} \cdot \mathrm{ha}^{-1}\right)$. We expected this herbicide to be phytotoxic to early seedling growth because of its inhibitory effect on root cell division (Barrett and Ashton,
1981; Jachetta et al.. 1979: Zilkah et al.. 1978). However, tomato plants are highly tolerant of napropamide due to rapid transport of the active compound from roots to shoots, where it is metabolized to nontoxic products (Barrett and Ashton, 1981; Murphy et al., 1983).

The significant reduction in dry weight of seedlings from the aged seed lot 15 days after emergence in greenhouse conditions compared to those of control and primed seedlings (Table 1) supports the concept that reduced and delayed seedling emergence are the first symptoms of seed deterioration, followed by a lower rate of seedling growth (McDonald, 1980). In field trials, the aged seed lot differed from the others in slower emergence, fewer emerged plants, and slightly delayed fruit maturity (Table 2), but relative growth rate and total yield did not differ due to seed quality. Similar results were observed for soybeans and maize, where lessvigorous seedlings showed more visual symptoms of herbicide injury, but with no reduction in yield (Johnson and Wax, 1979, 1981). Thus, deteriorated seeds that are subjected to biological or environmental stresses exhibit reduced field emergence, which may (Johnson and Wax, 1979) or may not (Burris, 1976; TeKrony and Egli, 1977; Yaklich and Kulik, 1979) be related to final yields, depending on the crop.

Primed seeds differed from untreated seeds only in a reduction in degree-days needed for emergence (9\% less than control in April and $6 \%$ less in May) (Tables 1 and 2). The earlier emergence of seedlings from primed seeds did not result in greater fruit maturity at harvest (Table 2). In contrast, the $47 \%$ greater degree-days to emergence of aged seeds than untreated seeds resulted in significantly greater percentages of green fruit at harvest in both field trials (Table 2). Considerable reductions in emergence time apparently are required in tomato to realize early fruit maturity due to the extended period re- quired for pollination and fruit set (Alvarado et al., 1987; Barlow and Haigh, 1987). In agreement with previous reports (Alvarado et al., 1987; Barlow and Haigh, 1987; Wolfe and Sims, 1982), total fruit fresh weight was not increased due to seed priming (Table 2).

In summary, although seed vigor influenced the timing and extent of emergence and metribuzin reduced the survival of seedlings, there was no significant interaction between seed vigor and herbicide tolerance in field trials. Under conditions favorable for herbicide injury, seedlings from low-vigor seeds showed lower tolerance to metribuzin than did seedlings from high-vigor seeds.

\section{Literature Cited}

Alvarado, A.D., K.J. Bradford, and J.D. Hewitt. 1987. Osmotic priming of tomato seeds: effects on germination, field emergence, seedling growth and fruit yield. J. Amer. Soc. Hort. Sci. 112:427-432.

Argerich, C.A. and K.J. Bradford. 1989. The effects of priming and ageing on seed vigour in tomato. J. Expt. Bot. 40:599-607.

Association of Official Seed Analysts. 1983. Seed vigor testing handbook. Assn. Offic. Seed Anal. Springfield, Ill.

Barlow, E.W.R. and A.M. Haigh. 1987. Effect of seed priming on the emergence, growth and yield of UC 82B tomatoes in the field. Acta Hort. 200:153-164.

Barrett, M. and F.M. Ashton. 1981. Napropamide uptake, transport and metabolism in corn (Zea mays) and tomato (Lycopersicon esculentum). Weed Sci. 29:697-703.

Baskerville, G.L. and P. Emin. 1969. Rapid estimations of heat accumulation from maximum and minimum temperatures. Ecology 50:514517

Burris, J.S. 1976. Seed/seedling vigor and field performance. J. Seed Technol. 1:58-74.

Frear, D.S., E.R. Mansager, M.R. Swanson, and F.S. Tanaka. 1983. Metribuzin metabolism in tomato: isolation and identification of $\mathrm{N}$-glucoside conjugate. Pest. Biochem. Physiol. 19:270-281.

Friensen, G.H. and A.S. Hamill. 1978. Influence of sunlight on metribuzin injury to transplanted tomatoes. Can. J. Plant Sci. 58:1115-1117.

Jachetta, J.J., S.R. Radosevich, and C.L. Elmore. 1979. Differential susceptibility of two pigweed (Amaranthus spp.) species to napropamide. Weed Sci. 27:189-191.

Johnson, R.R. and L.M. Wax. 1979. Soybean stand establishment and yield as affected by herbicides and cultural practices. Agron. J. 71:880884.

Johnson, R.R. and L.M. Wax. 1981. Stand establishment and yield of corn as affected by herbicides and seed vigor. Agron. J. 73:859863.

McDonald, M.B., Jr. 1980. Assessment of seed quality. HortScience 15:784-788.

Murphy, J.J., J. Didriksen, and R.A. Gray. 1973. Metabolism of 2-( a -naphthoxy)-N,Ndiethyl propionamide in tomato. Weed Sci. 21:11-15.

Phatak, S.C. and G.R. Stephenson. 1973. Influence of light and temperature on metribuzin phytotoxicity to tomato. Can. J. Plant Sci. 53:843-847.

Rajanna, B. and A.A. de la Cruz. 1977. Stand establishment and early growth of field crops as influenced by seed vigour and pesticide residues. Seed Sci. \& Technol. 5:71-85.

TeKrony, D.M. and D.B. Egli. 1977. Relation- 
ship between laboratory indices of soybean seed vigor and field emergence. Crop Sci. 17:573577.

Trebts, A. and W. Wieroska. 1975. Hemmung des photosynthetischen Electrontransports von Chloroplasten durch Metribuzen. Z. Naturforsch. 30C:499-504.

Wolfe, D.W. and W.L. Sims. 1982. Effects of osmoconditioning and fluid drilling of tomato seed on emergence rate and final yield. HortScience 17:936-937.

Wyse, D.L., W.F. Meggitt, and D. Penner. 1976. Factors affecting EPTC injury to navy bean. Weed Sci. 24:1-4.

Yaklich, R.W. and M.K. Kulik. 1979. Evaluation of vigor tests in soybean seeds: relationship of the standard germination test, seedling vigor classification, seedling length, and tetrazolium staining to field performance. Crop Sci. 19:247252.

Zilkah, S.P., P.F. Bocion, and J. Gressel. 1978. Target tissue for napropamide inhibition: effects on green and white callus cultures and seedlings. Weed Sci. 26:711-713. 